\title{
DKK3 Gene
}

National Cancer Institute

\section{Source}

National Cancer Institute. DKK3 Gene. NCI Thesaurus. Code C95419.

This gene plays a role in signaling and morphogenesis. 